
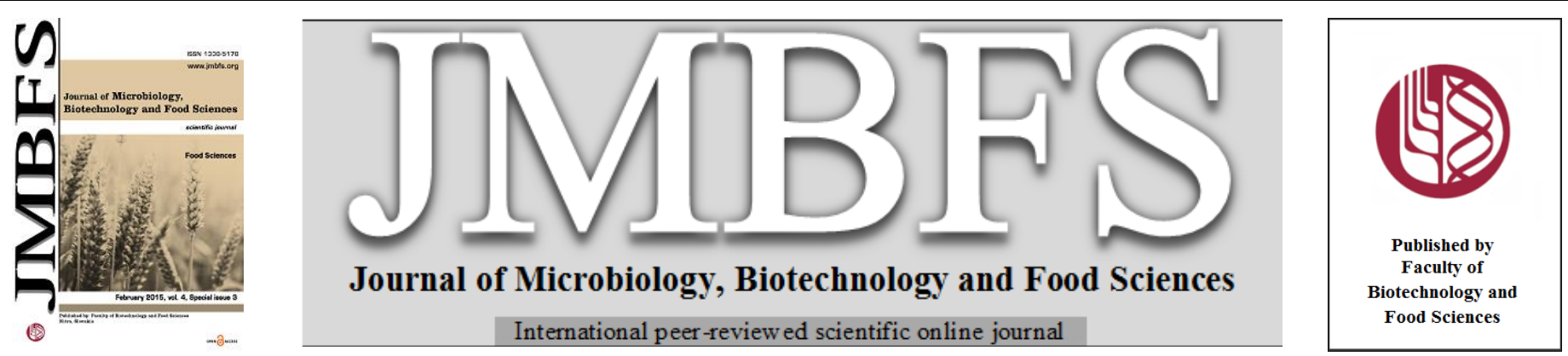

\title{
HEALTHY PROPERTIES OF ENDIVE (CICHORIUM ENDIVIA $\quad$ L.) DEPENDING ON THE VARIETY AND VEGETATIVE OF SEASON
}

\author{
Iwona Mentel*, Ewa Cieślik, Anna Sadowska-Rociek
}

Address(es): Ph.D. Iwona Mentel

University of Agriculture, Faculty of Food Technology, Department of Nutrition Technology and Consumption, 122 Balicka st, Kr aków 30-149, Poland, phone number: +48 126624832 .

*Corresponding author: i.mentel@ur.krakow.pl

doi: 10.15414/jmbfs.2015.4 special3.118-121

\section{ART ICLE INFO}

Received 1. 12.2014

Revised 6. 12. 2014

Accepted 7. 12. 2014

Published 2. 2. 2015

$\overline{\text { Short communication }}$ open $\partial_{\text {ACCESS }}$

\begin{abstract}
The endive (Cichorium endivia L.) is plant belonging to Asteraceae family. It is very popular vegetable in France, Italy and Germany. Endive because of its high content healthy components can be used in prevention against a lot of diseases.

The studies were conducted on two varieties of endive: 'Cigal' and 'Marconi' during vegetative of season: 2009 and 2010 . The research material was assessed for: dry matter, protein, diet ary fibre, ash, selected minerals ( $\mathrm{Ca}, \mathrm{Mg}, \mathrm{K}, \mathrm{P}, \mathrm{Na}, \mathrm{Fe}, \mathrm{Zn}, \mathrm{Mn}, \mathrm{Cu}$ ) leve ls and antioxidants (vitamin C, phenols components) contents. Also, the calculation of the energy value, carbohydrates and the antioxidant potential of ABTS were performed. The endive variety 'Cigal' was characterized higher content of calcium, magnesium, phosphorus, potassium, sodium, zinc and phenols components. While variety 'Marconi' contained more of dry matter, carbohydrates, dietary fibre, vitamin C, iron, copper and higher antioxidant activity. The studies showed statistically significant differences in terms of the content of components and antioxidant activity, between analysed varieties of vegetable and vegetation of season.
\end{abstract}

Keywords: Endive, healthy properties, variety, vegetative of season

\section{INTRODUCTION}

Endive (Cichorium endivia L.) belongs to the family Asteraceae, genus Cichorium. This vegetable is an annual plant and the leaves rosette, placed on a short stalk are an edible part of this plant (Nuez and Prohens, 2008; Alshehri and Elsayed, 2012). Endive has not special climate requirements, and it tolerates moderate frost. However, prolonged droughts cause that the plants knock in the flower stem. The soil humus curled, airy, with a neutral $\mathrm{pH}$ are the posts recommended for the cultivation of endive. Endive is characterized by a high content of nutrients. This vegetable contains more: calcium, phosphorus, iron and potassium in comparison to lettuce. Moreover, a lot of $\beta$-carotene, vitamin $\mathrm{C}$ and vitamin from group of $\mathrm{B}$ are in leaves of endive, bioactive substances such as: inulin and int ybine and also phenolic compounds (Hedges and Lister, 2005; Degl'Innocenti et al.,2008; Cieślik and Gajda, 2010). Due to the presence of biological substances, endive has got valuable healthy properties, and systematic consumption of this vegetable influences beneficially on digestive and cardiovascular system (Rice-Evans et al., 1997; Cieślik, 2009; Cieślik and Gę bu sia, 2011;). A lot of studies (Hasan et al.,1990; Achmed, et al., 2003; Alshhehri and Elsayed, 2012) conducted both in vitro and in vivo (with participation of laborat ory animals) showed very important influence of alcoholic extract of the plant of genus Cichorium on tumor cells growth. Due to the presence of antioxidant compounds including phenols components, the use of these extracts inhibits the development of carcinogenic structures.

The aim of study was to determine healthy properties and also antioxidant activity of endive (Cichorium endivia $\mathrm{L}$.) depending on variety and vegetative of season.

\section{MATERIAL AND METHODS}

\section{Material}

Experiment was conducted on two varieties of endive: 'Cigal' and 'Marconi' available in the dealing in 2009 and 2010 year. The samples were collected at 20 samples of each variety, which next washed up, dried and comminuted.

\section{Methods}

The content of vitamin $C$, phenols components and antioxidant activity was determined in the fresh material. The determination of: protein, ash, dietary fibre, mineral components contents was carried out after prior lyophilisation by using CHRIST LOC-1M ALPHA 1-4 apparatus. The dry mass content was done on fresh and lyophilised material. All obtained results were calculated for fresh mass basis. The dry mass was obtained by thermo-gravimetric method in dryer at 105 ${ }^{\circ} \mathrm{C}$ during $24 \mathrm{~h}$ (PN-ISO 1026:2000). The protein content was performed by Dumas method with TruSpec $\mathrm{N}$ analyser. The ash content was performed by thermo-gravimetric method by ashing in muffle furnace at $525^{\circ} \mathrm{C}$ during $12 \mathrm{~h}$ (PN-90/A-75101/08:1990+Az1:2002). The assessment of carbohydrates was obtained by method of calculation in accordance with methodology reported by Gron owska-Senger (2004). The dietary fibre content was determined according to AOAC 991.43 method (Association of Official Analytical Chemists International, 2006). The energy value was calculated with average Atwater coefficients (method of calculation) (Kunachowicz et al., 2005). For calculations, the average $-0.2 \mathrm{~g}$ content of fat was used (according to bibliography). The vitamin $\mathrm{C}$ content was estimated by titration as sum of ascorbic and dehydroascorbic acids (Krelowska-Kulas, 1993). Antioxidant activity was determined by using method according to $S$ wain and Hillis (1959). Phenols components was done by using Folin and Ciocalteu's phenol reagent in accordance with methodology reported by $\operatorname{Re}$ at al., (1999). The determination of phosphorous in endive was conducted using dry ashing followed by UV-Vis spectrophotometry with ammonium vanadomolybdatemethod (VM) (Cieślik et al., 2011). The determination of calcium, magnesium, potassium, sodium, iron and zinc was accomplished with atomic absorption spectrometry.

\section{Statistical analysis}

The analyses were done in three repetitions. The obtained results were submitted to statistical estimates two-way analysis of variance method at the significance level $\alpha=0.05$.

\section{RESULTS AND DISCUSSION}

The energy value fluctuated in the scope from $14,16-18.04 \mathrm{kcal} 100 \mathrm{~g}^{-1}$ of fresh weight (T ab. 1) irrespective of the variety and vegetative of season. The obt ained results were in accordance with data received by a lot of authors (Cieślik and Gajda, 2010; Elmadfa and Muskat, 2011; USDA, 2012), which showed that

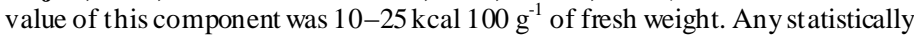
significant differences in energy value were not observed in analysed endives 
varieties. However, the obtained results differed significantly between the vegetative of season those varieties.

The average content of dry matter in assessed of rosette leaf endive ranged from 6.50-6.76 g $100 \mathrm{~g}^{-1}$ of fresh weight (Tab. 1). Significant differences in dry matter contents between vegetative of season and interaction between variety and vegetative of season (Tab. 2) were found. Moreover, the significance of st atistical differences was not noticed for studied varieties. The obtained results were lower in comparison to Adamczewska-Sowińska and Uklańska, (2009), which

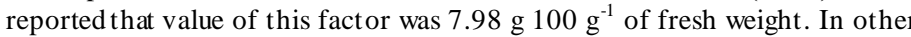
researches, Cieślik and Gajda, (2010) and Elmadfa and Muskat, (2011) the

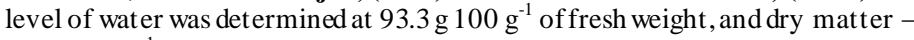

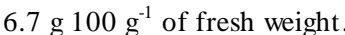

There were not significant differences in protein contents within the varieties and

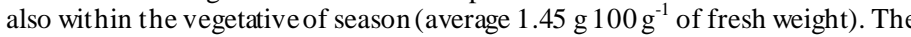
obtained results were in accordance with those reported by a lot of authors (Ci eślik and Gajda, 2010; Elmadfa and Muskat, 2011; USDA, 2012), average 1.25-1.8 g protein $100 \mathrm{~g}^{-1}$ of fresh weight.

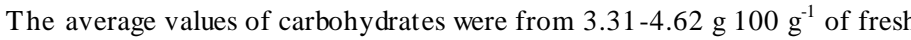
weight. There were significant differences noticed only between vegetative of seasons. The obtained results were higher than those received by other authors (Cieślik and Gajda, 2010; Emadfa and Muskat, 2011; USDA, 2012). For diet ary fibre content any significant differences bet ween varieties of endive and between vegetative of seasons were not found. The average values were from

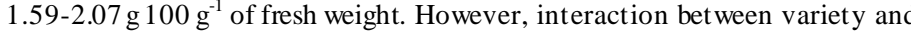
vegetative of season was observed. The obtained amounts of dietary fibre in leaves of endive were higher than those reported by Wiąckowski, (1995), which

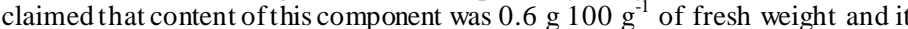

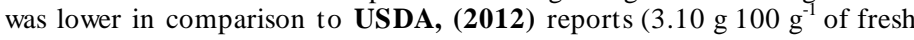
weight).

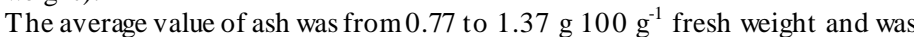
close to those showed by other authors for another Asteraceae (1-1.76 g $100 \mathrm{~g}^{-1}$ of fresh weight) (Cieślik et al.,2012; Mentel et al.,2012). The statistical test s showed significant differences in ash content between the varieties (Tab. 2).

Table 1 Energy value and selected nutritive and non-nutritive components of endive (per 100 grams fresh weight)

\begin{tabular}{|c|c|c|c|c|c|c|}
\hline \multirow{2}{*}{$\begin{array}{l}\text { Variety } \\
\text { Component }\end{array}$} & \multicolumn{2}{|c|}{ 'Cigal' } & \multicolumn{2}{|c|}{ 'Marconi' } & \multirow{2}{*}{$\begin{array}{l}\text { 'Cigal' } \\
\text { Average }\end{array}$} & \multirow{2}{*}{$\begin{array}{l}\text { 'Marconi' } \\
\text { Average }\end{array}$} \\
\hline & 2009 & 2010 & 2009 & 2010 & & \\
\hline Energy value, kcal $100 \mathrm{~g}^{-1}$ & 18.04 & 14.16 & 17.60 & 14.44 & 16.10 & 16.02 \\
\hline SD & 0.74 & 2.98 & 1.84 & 1.36 & 2.90 & 2.26 \\
\hline Dry matter, g $100 \mathrm{~g}^{-1}$ & 6.63 & 6.37 & 7.50 & 6.02 & 6.50 & 6,76 \\
\hline $\mathrm{SD}$ & 0.26 & 0.47 & 0.05 & 1.05 & 0.38 & 1.05 \\
\hline Protein, g $100 \mathrm{~g}^{-1}$ & 1.04 & 1.85 & 1.75 & 1.14 & 1.45 & 1,45 \\
\hline $\mathrm{SD}$ & 0.15 & 0.14 & 0.44 & 0.15 & 0.45 & 0.44 \\
\hline Carbohydrates, g $100 \mathrm{~g}^{-1}$ & 4.62 & 3.31 & 4.50 & 3.61 & 3.97 & 4.06 \\
\hline $\mathrm{SD}$ & 0.62 & 0.95 & 0.34 & 0.46 & 1.02 & 0.60 \\
\hline Including dietary fibre, g $100 \mathrm{~g}^{-1}$ & 1.60 & 2.07 & 2.30 & 1.59 & 1.84 & 1.95 \\
\hline $\mathrm{SD}$ & 0.35 & 0.20 & 1.05 & 0.15 & 0.37 & 0.81 \\
\hline Ash, g $100 \mathrm{~g}^{-1}$ & 0.77 & 1.01 & 1.05 & 1.07 & 0.89 & 1.06 \\
\hline $\mathrm{SD}$ & 0.23 & 0.04 & 0.06 & 0.24 & 0.20 & 0.17 \\
\hline
\end{tabular}

SD - standard deviation

Table 2 Analysis of variance for energy value and selected nutritive and nonnutritive components of endive

\begin{tabular}{|c|c|c|}
\hline \multicolumn{3}{|l|}{ Energy value } \\
\hline Factor & Statistic value of F & Level p \\
\hline Variety & 0.12 & 0.73 \\
\hline Vegetative of season & 17.94 & 0.00 \\
\hline Interaction $\mathrm{VxVs}$ & 0.65 & 0.42 \\
\hline \multicolumn{3}{|l|}{ Dry mass } \\
\hline Factor & Statistic value of F & Level $\mathrm{p}$ \\
\hline Variety & 1.15 & 0.29 \\
\hline Vegetative of season & 12.72 & 0.00 \\
\hline Interaction $\mathrm{VxVs}$ & 6.39 & 0.01 \\
\hline \multicolumn{3}{|l|}{ Protein } \\
\hline Factor & Statistic value of F & Level p \\
\hline Variety & 0.00 & 0.97 \\
\hline Vegetative of season & 0.98 & 0.33 \\
\hline Interaction $\mathrm{VxVs}$ & 47.65 & $1.05 \mathrm{E}-06$ \\
\hline \multicolumn{3}{|l|}{ Carbohydrates } \\
\hline Factor & Statistic value of F & Level $\mathrm{p}$ \\
\hline Variety & 0.12 & 0.73 \\
\hline Vegetative of season & 17.94 & 0.00 \\
\hline Interaction $\mathrm{VxVs}$ & 0.65 & 0.42 \\
\hline \multicolumn{3}{|l|}{ Dietary fibre } \\
\hline Factor & Statistic value of $F$ & Level p \\
\hline Variety & 0.24 & 0.63 \\
\hline Vegetative of season & 0.25 & 0.62 \\
\hline Interaction $\mathrm{Vx} V \mathrm{~s}$ & 6.50 & 0.02 \\
\hline \multicolumn{3}{|l|}{ Ash } \\
\hline Factor & Statistic value of F & Level $\mathrm{p}$ \\
\hline Variety & 6.03 & 0.02 \\
\hline Vegetative of season & 3.38 & 0.08 \\
\hline Interaction $\mathrm{Vx} \mathrm{Vs}_{\mathrm{s}}$ & 2.66 & 0.11 \\
\hline
\end{tabular}

Interaction $\mathrm{VxVs}$ - interaction variety and vegetative of season.

The value in the table in bold represent statistically significant differences at the significance level $\alpha=0.05$

Studies conducted on two varieties of endive showed statistical significant higher content of calcium in leaves of variety 'Cigal'. The average content of this component was from 62.06-67.72 $\mathrm{g} 100 \mathrm{~g}^{-1}$ of fresh weight (Tab. 3). The obtained results were in accordance with those reported by Koudela and Petrríkova, (2007) (33.2 - 85.1 mg $100 \mathrm{~g}^{-1}$ of fresh weight), and higher in comparison to Cieślik and Gajda, (2010) and Elmadfa and Muskat, (2011) reports (54 mg $100 \mathrm{~g}^{-1}$ fresh weight). Significant differences in calcium average were found also between vegetative of seasons and interaction between variety and vegetative of season was noticed.

The magnesium content in assessed varieties of Cichorium endivia ranged from

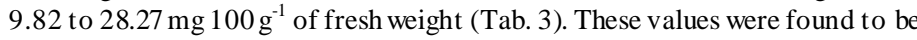
close to those obtained by Kou dela and Petříkova, (2007) for different varieties of this vegetable (12.6 - $41.7 \mathrm{mg} 100 \mathrm{~g}^{-1}$ of fresh weight) and Elmadfa and Muskat, (2011) (10 mg $100 \mathrm{~g}^{-1}$ of fresh weight). On the basis of statistical analysis, significant differences were shown between vegetative of seasons and interaction between variety and vegetative of season was observed.

The potassium level was different between the varieties, vegetative of seasons and interaction between variety and vegetative of season was noticed. In 2009 year, variety 'Marconi' characterized by a lower level of these component (166.20 mg $100 \mathrm{~g}^{-1}$ of fresh weight). Moreover, in the next year, content of

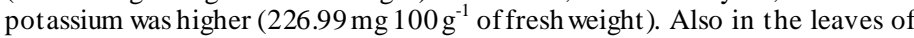
endive - variety 'Cigal', significant differences was observed for two years of studies. The result s obtained were lower in comparison to Cieślik and Gajda, (2010) (346 mg $100 \mathrm{~g}^{-1}$ of fresh weight) and Koudela and Petříkova, (2007) $\left(248.3-615.5 \mathrm{mg} 100 \mathrm{~g}^{-1}\right.$ of fresh weight).

The studies varieties had st atistical significant differences in level of phosphorus. Variety 'Cigal' characterized a higher content of this macroelement, average $33.70 \mathrm{mg} 100 \mathrm{~g}^{-1}$ of fresh weight (Tab. 3). Moreover, the significant differences were noticed in value of phosphorus between vegetative of seasons and interaction between variety and vegetative of season. The obtained amounts were

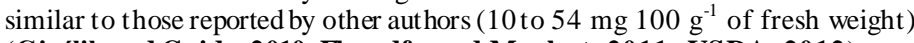
(Cieślik and Gajda, 2010; Emadfa and Muskat, 2011; USDA, 2012).

The assessed varieties: 'Cigal' and 'Marconi' contained out standingly higher sodium in comparison to results obtained by other (Koudela and Petrríkova 2007; Rekowska and Jurga-Szlempo, 2011). The highest level of those macroelement was observed in variety 'Cigal' in the first year $\left(142.63 \mathrm{mg} 100 \mathrm{~g}^{-1}\right.$ of fresh weight), however the lowest was noticed in leaves of variety 'Marconi' in 2010 year $\left(15.84 \mathrm{mg} 100 \mathrm{~g}^{-1}\right.$ of fresh weight $)$. The statistically significant differences were shown in content of sodium between varieties, vegetative of seasons and also variety and vegetative of seasons ( Tab. 4).

The result s of iron level were ranged from 3.78-6.51 mg $100 \mathrm{~g}^{-1}$ of fresh weight The values obtained were significantly much higher than these noticed by other authors. According to Cieślik and Gajda, (2010) and also Elmadfa and Muskat, (2011), the values of these component was $1.4 \mathrm{mg} 100 \mathrm{~g}^{-1}$ of fresh weight. Moreover, USDA, (2012) reported the iron level for endive to be at 0.28 $\mathrm{mg} 100 \mathrm{~g}^{-1}$ of fresh weight.

The lowest amount of zinc was observed in the first year of studies in Cichorium

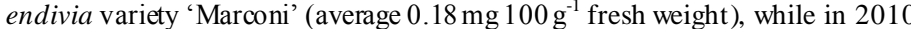
year content of those component in leaves of this variety significantly increased (Tab. 3). The statistical significance differences were shown in level of zinc in vegetative of seasons. The data received during the study were much lower than indicated by the USDA, (2012). 
The average content of manganese in leaves of endive was the same for both of varieties $\left(0.43 \mathrm{mg} 100 \mathrm{~g} \mathrm{~g}^{-1}\right.$ of fresh weight $)$. There were statistical significant differences in level of this component between vegetative of seasons (Tab. 4). The values received, were in accordance to those reported by USDA, (2012) (0.42 mg $100 \mathrm{~g}^{-1}$ of fresh weight $)$.
Basing on results from conducted studies, it was found that the content of copper

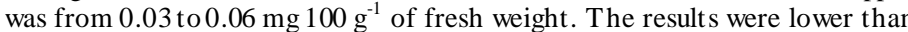
those noticed by USDA, (2012). There were no significant differences showed.

\begin{tabular}{|c|c|c|c|c|c|c|}
\hline \multirow{2}{*}{$\begin{array}{l}\text { Variety } \\
\text { Component }\end{array}$} & \multicolumn{2}{|c|}{ 'Cigal' } & \multicolumn{2}{|c|}{ 'Marconi' } & \multirow{2}{*}{$\begin{array}{l}\text { 'Cigal' } \\
\text { Average }\end{array}$} & \multirow{2}{*}{$\begin{array}{c}\text { 'Marconi' } \\
\text { Average }\end{array}$} \\
\hline & 2009 & 2010 & 2009 & 2010 & & \\
\hline Calcium, mg $100 \mathrm{~g}^{-1}$ & 27.66 & 107.77 & 68.77 & 55.35 & 67.72 & 62.06 \\
\hline SD & 1.35 & 4.92 & 1.97 & 2.27 & 41.98 & 7.29 \\
\hline Magnesium, mg $100 \mathrm{~g}^{-1}$ & 9.82 & 28.27 & 15.18 & 19.45 & 19.05 & 17.32 \\
\hline SD & 3.05 & 1.98 & 2.28 & 1.42 & 9.94 & 2.87 \\
\hline Potassium, mg $100 \mathrm{~g}^{-1}$ & 184.52 & 272.15 & 166.20 & 226.99 & 228.34 & 196.60 \\
\hline $\mathrm{SD}$ & 9.05 & 5.51 & 1.53 & 3.50 & 46.32 & 31.85 \\
\hline Phosphorus, mg $100 \mathrm{~g}^{-1}$ & 30.82 & 36.58 & 27.76 & 29.22 & 33.70 & 28.49 \\
\hline SD & 0.98 & 2.03 & 1.16 & 0.82 & $\mathbf{3 . 3 7}$ & 1.22 \\
\hline Sodium, $\mathrm{mg} 100 \mathrm{~g}^{-1}$ & 142.63 & 30.47 & 45.54 & 15.84 & 86.55 & 30.69 \\
\hline SD & 10.72 & 0.49 & 2.29 & 2.41 & 59.02 & 15.67 \\
\hline Iron, mg $100 \mathrm{~g}^{-1}$ & 0.75 & 6.80 & 4.05 & 8.96 & 3.78 & 6.51 \\
\hline SD & 0.38 & 1.49 & 0.27 & 0.28 & 3.32 & 2.58 \\
\hline Zinc, mg $100 \mathrm{~g}^{-1}$ & 0.27 & 0.40 & 0.18 & 0.39 & 0.34 & 0.29 \\
\hline $\mathrm{SD}$ & 0.09 & 0.04 & 0.12 & 0.09 & 0.10 & 0.15 \\
\hline Manganese, $\mathrm{mg} 100 \mathrm{~g}^{-1}$ & 0.20 & 0.66 & 0.28 & 0.58 & 0.43 & 0.43 \\
\hline SD & 0.16 & 0.18 & 0.19 & 0.12 & 0.29 & 0.22 \\
\hline Copper, mg $100 \mathrm{~g}^{-1}$ & 0.03 & 0.04 & 0.06 & 0.05 & 0.04 & 0.06 \\
\hline $\mathrm{SD}$ & 0.02 & 0.01 & 0.02 & 0.03 & 0.02 & 0.02 \\
\hline
\end{tabular}

Table 4. Analysis of variance for selected minerals components of endive

\begin{tabular}{|c|c|c|}
\hline Calcium & & \\
\hline Factor & Statistic value of $F$ & Level p \\
\hline $\begin{array}{l}\text { Variety } \\
\text { Varis }\end{array}$ & 21.92 & 0.00 \\
\hline Vegetative of season & 762.11 & 0.00 \\
\hline Interaction $\mathrm{Vx} V \mathrm{~s}$ & 1498.81 & 0.00 \\
\hline \multicolumn{3}{|l|}{ Magnesium } \\
\hline Factor & Statistic value of $F$ & Level $p$ \\
\hline Variety & 3.51 & 0.08 \\
\hline Vegetative of season & 151.66 & 0.00 \\
\hline Interaction VxVs & 59.01 & 0.00 \\
\hline \multicolumn{3}{|l|}{ Potassium } \\
\hline Factor & Statistic value of F & Level $\mathrm{p}$ \\
\hline Variety & 190.63 & 0.00 \\
\hline Vegetative of season & 1042.22 & 0.00 \\
\hline Interaction Vx Vs & 34.09 & 0.00 \\
\hline \multicolumn{3}{|l|}{ Phosphorus } \\
\hline Factor & Statistic value of $F$ & $\overline{\text { Level } p}$ \\
\hline Variety & 91.55 & 0.00 \\
\hline Vegetative of season & 43.84 & 0.00 \\
\hline Interaction VxVs & 15.57 & 0.00 \\
\hline \multicolumn{3}{|l|}{ Sodium } \\
\hline Factor & Statistic value of $F$ & Level $p$ \\
\hline Variety & 593.58 & 0.00 \\
\hline Vegetative of season & 957.17 & 0.00 \\
\hline Interaction VxVs & 323.44 & 0.00 \\
\hline \multicolumn{3}{|l|}{ Iron } \\
\hline Factor & Statistic value of F & Level $\mathrm{p}$ \\
\hline Variety & 71.20 & 0.00 \\
\hline Vegetative of season & 286.69 & 0.00 \\
\hline Interaction $\mathrm{Vx} V s$ & 3.09 & 0.09 \\
\hline \multicolumn{3}{|l|}{ Zinc } \\
\hline Factor & Statistic value of $F$ & Level $\mathrm{p}$ \\
\hline 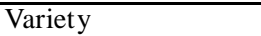 & 1.93 & 0.18 \\
\hline Vegetative of season & 21.42 & 0.00 \\
\hline
\end{tabular}

\begin{tabular}{lll} 
Interaction VxVs & 1.00 & 0.33 \\
\hline Manganese & & \\
\hline Factor & Statistic value of F & Level $\mathrm{p}$ \\
\hline Variety & 0.00 & 1.00 \\
Vegetative of season & $\mathbf{3 2 . 3 9}$ & 0.00 \\
Interaction VxVs & 1.37 & 0.26 \\
\hline Copper & & \\
\hline Factor & Statistic value of $\mathrm{F}$ & Level $\mathrm{p}$ \\
\hline Variety & 3.23 & 0.09 \\
Vegetative of season & 0.00 & 0.94 \\
Interaction VxVs & 0.64 & 0.43 \\
\hline Interaction VxVs - interaction variety and vegetative of season
\end{tabular}

Interaction VxVs - interaction variety and vegetative of season
The value in the table in bold represent statistically significant differences at the significance level $\alpha=0.05$

The average value of vitamin $C$ in leaves of endive was from $9.86-13.30 \mathrm{mg} 100$ $\mathrm{g}^{-1}$ of fresh weight (Tab. 5). There were significant differences in level of this component bet ween varieties and interaction between variety and vegetative of season (Tab. 6). The conducted studies showed that content of this vitamin in variety 'Cigal' was comparable to data received by other authors and not much higher for variety 'Marconi'. According to Llorach et al., (2008), MüllerNothmann, (2008), Cieślik and Gajda, (2010) and Emadfa and Muskat, (2011), the vitamin C content in the fresh of endive was at the level of 10-10.2 $\mathrm{mg} 100 \mathrm{~g}^{-1}$ fresh weight.

As a result of the researches, differences in content of phenols components in assessed varieties and between vegetative of seasons were observed (Tab. 6). Moreover, the interaction between variety and vegetative of season was revealed. In the second year, the studied varieties were characterised by higher level of polyphenols (average: 'Cigal': $99.87 \mathrm{mg} \mathrm{GAE} 100 \mathrm{~g}^{-1}$ and 'Marconi': $99.73 \mathrm{mg}$ GAE $\left.100 \mathrm{~g}^{-1}\right)$ (Tab. 5). The data were lower to those noticed by Llorach et al., (2008) (259.1 mg $100 \mathrm{~g}^{-1}$ of fresh weight).

Higher values of antioxidant activity measured by the ability to free radicals scavenging ABTS in the examinations were determined (3.61 mg Trolox $\mathrm{g}^{-1}$

'Cigal' and $4.67 \mathrm{mg}$ Trolox $^{-1}$ - 'Marconi'), with respect to those obtained by Llorach et al., (2008) (0.934 $\mathrm{mg}$ Trolox $\left.\mathrm{g}^{-1}\right)$.

Table 5. Content of vitamin C, phenols components and antioxidant activity ABTS of endive (per $100 \mathrm{~g}$ fresh weight)

\begin{tabular}{|c|c|c|c|c|c|c|}
\hline \multirow{2}{*}{$\begin{array}{l}\text { Variety } \\
\text { Component }\end{array}$} & \multicolumn{2}{|c|}{ 'Cigal' } & \multicolumn{2}{|c|}{ 'Marconi' } & \multirow{2}{*}{$\begin{array}{c}\text { 'Cigal' } \\
\text { Average }\end{array}$} & \multirow{2}{*}{$\begin{array}{c}\text { 'Marconi' } \\
\text { Average }\end{array}$} \\
\hline & 2009 & 2010 & 2009 & 2010 & & \\
\hline Vitamin C, mg $100 \mathrm{~g}^{-1}$ & 10.50 & 9.22 & 12.40 & 14.19 & 9.86 & 13.30 \\
\hline $\mathrm{SD}$ & 0.62 & 0.43 & 1.29 & 1.94 & 0.84 & 1.83 \\
\hline Phenols components, & 46.69 & 99.87 & 33.60 & 99.73 & 73.28 & 66.67 \\
\hline $\begin{array}{l}\text { mg GAE } 100 \mathrm{~g}^{-1} \\
\text { SD }\end{array}$ & 2.77 & 1.14 & 0.36 & 0.27 & 27.85 & 34.54 \\
\hline $\begin{array}{l}\text { Antioxidant activity ABTS, } \\
\mathrm{mg} \text { Trolox } 100 \mathrm{~g}^{-1}\end{array}$ & 4.15 & 3.06 & 4.54 & 4.80 & 3.61 & 4.67 \\
\hline $\mathrm{SD}$ & 0.01 & 0.79 & 0.02 & 1.22 & 0.78 & 0.83 \\
\hline
\end{tabular}


Table 6. Analysis of variance for vitamin C, phenols components and antioxidant activity ABTS of endive

\begin{tabular}{lll}
\hline Vitamin C & & \\
\hline Factor & Statistic value of F & Level p \\
\hline Variety & $\mathbf{4 6 . 9 3}$ & 0.00 \\
Vegetative of season & 0.25 & 0.62 \\
Interaction Vx Vs & $\mathbf{9 . 3 7}$ & 0.01 \\
\hline Phenols components & & \\
\hline Factor & Statistic value of F & Level p \\
\hline Variety & $\mathbf{1 1 4 . 7 4}$ & 0.00 \\
Vegetative of season & $\mathbf{9 3 3 0 . 9 3}$ & 0.00 \\
Interaction Vx Vs & $\mathbf{1 0 9 . 7 9}$ & 0.00 \\
\hline Antioxidant activity ABTS & & \\
\hline Factor & Statistic value of F & Level p \\
\hline Variety & $\mathbf{1 2 . 9 9}$ & 0.00 \\
Vegetative of season & 1.95 & 0.18 \\
Interaction Vx Vs & $\mathbf{5 . 1 6}$ & 0.03 \\
\hline Interaction VxVs interaction variety and
\end{tabular}

Interaction $\mathrm{VxVs}$ - interaction variety and vegetative of season

The value in the table in bold represent statistically significant differences at the significance level $\alpha=0.05$

\section{CONCLUSION}

The studies showed that content of: ash, calcium, potassium, phosphorus, sodium, iron, vitamin C, phenols components and antioxidant activity depended significantly on variety. Moreover, the statistically significant differences of energy value and content of: dry matter, carbohydrates, calcium, magnesium, potassium, phosphorus, sodium, iron, zinc, manganese and phenols components were noticed between vegetative of seasons.

On the base received of results noticed that endive - variety 'Marconi' was characterized by higher level of: dry matter, carbohydrates, dietary fibre, vitamin $\mathrm{C}, \mathrm{Fe}, \mathrm{Cu}$ and antioxidant activity $\mathrm{ABTS}$, which testify to its higher nutritive value.

The abundance of nut ritive components in endive allows concluding that it is not only vegetable but also precious homeopathic herbal medicine with great healthy feat ures. It shows prebiotic activity because of fructans presence. This vegetable because of its high contains content of healthy components, can be used in prophylaxis of digestive disorders, as medicament in supporting of cardiovascular circulation for retarding of ageing processes and first of all for in blood diseases such as anaemia. Also because of inulin presence endive is recommended for diabetes as low glycemic index vegetable.

\section{REFERENCES}

ADAMCZEWSKA-SOWIŃSKA, K., UKLAŃSKA, C.M. 2009. Biological value of the endive cultivars in the spring and autumn culture. Advances of Agricultural Sciences Issues, 539, 31-36.

ACHMED, B., T AWFEQ, A.A.-H., ABU, B.S. 2003. Antihepatotoxic Activity of Seeds of Cichorium intybus. Journal of Ethnopharmacoly, 87, $237-240$. http://dx.doi.org/10.1002/hep1840120323

ALSHEHRI, A., ELSAYED, H.E. 2012. Molecular and biochemical evaluation of antiproliferative effect of (Cichorium endivia, L.) phenolic extracts on breast cancer cell line: MCF7. Journal of Biotechnology and Pharmaceutical Research, $3,74-82$.

AOAC (Association of Official Analytical Chemist s International). 2006. Official method 991.43. Total, soluble and insoluble fibre in foods enzymatic gravimetric method, Mes-Tris Buffer.

CIEŚLIK, E., 2009. Healthy properties of the vegetables. Advances of Agricultural Sciences Issues, 539, 87-97.

CIEŚLIK E., GAJDA I., 2010. Nutritional value and pro-healthy properties of endive (Cichorium endivia L.). Progress in Phytotherapy, 4, 224-228.

CIEŚLIK E., GEBUSIA A., 2011. Functional foods with fructans added. Food. Science. Technology. Quality, 2, $27 \quad-\quad 37$. http://dx.doi.org/10.15193/zntj/2011/75/027-037

CIEŚLIK, E. SADOWSKA-ROCIEK, A., SURMA-ZADORA, M., SIEJA, K., WAŁKOWSKA I. 2011 . The level of phosphorus in inst ant soups and processed cheeses. Annals of nutrition and metabolism (Proceding of the work of the European Nutrition Conference) Madrid: volume 58, supplement 3, 92.

CIEŚLIK, E., GEBUSIA, A. KOŚCIEJ, A. 2012. Yacon (Smallanthus sonchifolius (Poepp. et Endl.) H. Robinson) - tuber with healthy properties. Progress in Phytotherapy, 2, 113-118.

DEGL'INNOCENTI, E., PARDOSSI, A., TATTINI, M., GUIDI, L. 2008 Phenolic compounds and antioxidant power in minimally processed salad. Journal of FoodBiochemistry, 32, 642-653. http://dx.doi.org/10.1111/j.17454514.2008.00188.x

ELMADFA, J., MUSKAT, E. 2011. Great tables of calories and nutritive values. Warsaw: Muse, 23 p. ISBN 978-83-7495-993-3.

GRONOWSKA-SENGER, A. 2004. Bases of the bioevaluation of the food. Warsaw: Publishing Company SGGW, 5 p. ISBN 8372445532.
HASAN F., JEFFERS L.J., DE MEDINA M., REDDY K.R., PARKER T., SCHIFF E.R., HOUGHT ON M., CHOO Q.L., KUO G., 1990. Hepatit is Cassociated hepatocellular carcinoma. Hepatology, $12,589-591$. http://dx.doi.org/10.1111/j.1745-4514.2008.00188.x

HEDGES, L.J., LISTER, C.E. 2005. Nutritional at tributes of salad vegetables. Crop\&Food Research Confidential Report, N. 1473. http://vegetable.co.nz/resources/1files/pdf/booklet_salad__ foodreport.pdf (accessed August 2005).

KOUDELA, M., PETŘÍKOVÁ, K. 2007. Nutritional compositions and yield of endive cultivars - Cichorium endivia L. Horicultural. Science, 34, 6-10. KREŁOWSKA-KUŁAS, M. 1993. The examination of the quality of food products. Warszawa: Polish Economic Publishing Company, 163-166 p ISBN 8320809029.

KUNACHOWICZ,H., NADOLNA, I., IWANOW, K., PRZYGODA, B. 2005. The nutritional value of chosen food products and typical dishes. Warszawa: Medical Publisher PZWL, 9 p. ISBN 9788320043419.

LLORACH, R., MART ÍNEZ-SÁNCHEZ, A., TOMÁS-BARBERÁN, F.A., GIL, M.I., FERRERES, F. 2008. Characterisation of polyphenols and antioxidant properties of five let tuce varieties and escarole. Food Chemistry, 108, 1028-1038. http://dx.doi.org/10.1016/j.foodchem.2007.11.032

MENTEL, I., CIEŚLIK, E., WAŁKOWSKA, I., SIEJA, K. 2012. Content of nutritive components, diet ary fibre and energy value of artichoke depending on the variety. Acta Scientiarum Polonorum Technologia Alimentaria , 11, 109-115. MÜLLER-NOTHMANN, S.D. 2008. Tables of vitamins. Warszawa: Publishing Company RM, 37 p. ISBN 9788372436207.

NUEZ, F., PROHENS, J. (ed.) 2008. Vegetables I. Handbook of plant Breeding. California: Springer, $\quad 3-48 \quad$ p $\quad$ ISBN $\quad 978 \quad 0 \quad 387 \quad 722917$. http://dx.doi.org/10.1007/978-0-387-30443-4

PN-ISO 1026:2000. Fruit and vegetable products - Determination of dry matter kontent by dryling under reduced pressure and of water content by azeotropic distillation. Polish Standards Committee. Standard endorsed on 8 May. PN-90/A-75101/08:1990+Az1:2002. Fruit and vegetable products. Preparation of samples and testing methods. Determination of total ash content and its alkalinity. Polish Standards Committee. Standard endorsed on 18 December. RE, R., PELLEGRINI, N., PROTEGGENTE, A., PANNALA, A., YANG, M., RICE-EVANS, C. 1999. Antioxidant activity applying an improved ABT S radical cation decolorizing assay. Free Radical. Biologyand Medicine, 26, 1231 1237. http://dx.doi.org/10.1016/s0891-5849(98)00315-3

REKOWSKA, E., JURGA-SZLEMPO, B. 2011. Comparison of the content of some chemical compounds in two endive cultivars grown on an open field (Cichorium Endivia L.). Journal of Elementology, 16, 247-253. http://dx.doi.org/10.5601/jelem.2011.16.2.08

RICE-EVANS, C.A., MILlER, N.J., PAPGANGA, G. 1997. Antioxidant properties of phenolic compounds. Trends in Plant Science, 2, 152-159. http://dx.doi.org/10.1016/s1360-1358(97)01018-2

SWAIN, T., HILLI,SW.E. 1959. The phenolic constituents of Prunus domestica I. The quantitative analysis of phenolic constituents. Journal of the Science of Food and A griculture, 10, 63-68. http://dx.doi.org/10.1002/jsfa.2740100110 USDA 2012. National Nutrient data base. Agricultural Research Service, United States Department of Agriculture. http://www.ars.usda.gov/services/docs.htm?docid=8964 (accessed 2012). WIĄCKOWSKI, S.K. 1995. Trying environmental assessment of nutrition, food and nut rients. Warsaw: Publishing Company PWN, 200p. ISBN 8301116862. 